\title{
Manipulação, Tradução Literária e Identidade Nacional
}

\author{
Maribel MALTA PARADINHA \\ Leitora do Instituto Camões no México \\ Professora Visitante na Universidad Nacional Autónoma de México
}

La polémica en torno a las Lettres portugaises originó una contienda literaria entre Portugal y Francia durante más de dos siglos. Publicada en Francia en 1669 como una traducción de cinco cartas de amor anónimas de una religiosa portuguesa escritas a un militar francés, esta obra fue reivindicada por ambos países. Para Portugal, la traducción de esta obra significó, durante el llamado "Siglo del Nacionalismo Portugués (1870-1975)", la recuperación de un patrimonio literario necesario para la identidad nacional. Este trabajo discurre sobre la utilización ideológica de la traducción literaria al servicio de la Nación y señala el empobrecimiento de la producción literaria (casi exclusivamente propagandística) en un Portugal excesivamente ensimismado, nostálgico de su pasado de gran imperio mundial y consumido en la revalorización nacional.

PALABRAS CLAVE: manipulación, traducción literaria, identidad nacional, Portugal, Francia.

The polemic concerning the Lettres portugaises started a literary controversy between Portugal and France which lasted for more than two centuries. Both countries have laid claim to the authorship of those letters, first published in France in 1669 as a translation of five anonymous love letters from a Portuguese nun to a French army officer. For Portugal, the translation of these love letters meant the recovery of a literary heritage essential for the construction of national identity in the so-called "century of Portuguese Nationalism (1870's-1975)". This work reflects on the ideological use of translation serving the Nation interests and points out the impoverishment of the national literary production (almost exclusively propagandistic) in a Portugal too lost in thought, nostalgic of its great world empire and consumed with the national reassessment.

KEY WORDS: manipulation, literary translation, national identity, Portugal, France.

Ningún problema tan consustancial con las letras y con su modesto misterio como el que propone una traducción.

Jorge Luis Borges, "Las versiones homéricas", Obras completas 
[A]ll translation implies a degree of manipulation of the source text for a certain purpose.

Theo Herman

\section{Introdução}

As cartas da religiosa portuguesa, como mais comummente são conhecidas, foram fonte de interesse de numerosos investigadores não só em Portugal, como em vários pontos do mundo, não só pela sua qualidade literária, mas também (e, diríamos mesmo, sobretudo) pela polémica ${ }^{1}$ em que se encontram envoltas. As cartas portuguesas foram, durante muito tempo, alvo de contendas literárias entre França e Portugal. Sobre a génese deste enigma literário, de grande êxito em toda a Europa e, provavelmente, em todo o mundo, lembraremos, apenas, aqui, que se trata de uma obra epistolar (composta por cinco —ou em algumas edições por sete- cartas), editadas em 1669 pelo conhecido livreiro Claude Barbin. Desde então, escrever à portuguesa ou escrever uma portuguesa foram expressões que ficaram para sempre conhecidas em alguns países da Europa, e são empregues quando se pretende referir a beleza da escrita de cartas de amor ou a intensidade do sentimento amoroso, conferindo ao amor português um carácter excessivo, arrebatado e muito próprio.

\section{Problemática}

Tratando-se de uma obra que viu a luz do dia como uma tradução anónima de um autor também ele anónimo ${ }^{2}$ sobre os amores probidos tão ao gosto da sociedade francesa do século XVII, a obra gerou rapidamente reescritas, traduções e uma forte polémica

\footnotetext{
${ }^{1}$ Trata-se de cinco cartas que apareceram publicamente em 1669, em França, escritas em francês. No momento em que pela primeira vez foram publicadas pelo livreiro Barbin, surgiam como sendo cartas anónimas de uma religiosa portuguesa "traduites en françois". Estas cartas surgiram numa época em que França apreciava a literatura de cordel e os amores proibidos. Assim, tratando-se dos amores de uma freira e mais ainda portuguesa o público francês teria nestas cinco cartas tudo aquilo que apreciava e que procurava na literatura de então: os portugueses tinham fama de ser homens e mulheres muito amorosos, de paixões excessivas, extremamente católicos e, portanto, conservadores. Isto levou alguns portugueses a defender a tese do oportunismo livreiro de Barbin. Desconhecidas em Portugal durante mais de 150 anos, quando surgiu a primeira tradução lusa de Filinto Elísio, começaram a surgir figuras importantes no panorama cultural português (intelectuais, escritores, tradutores, políticos e historiadores) que afirmavam que as cartas eram portuguesas e que tentavam provar essa mesma origem portuguesa da obra. Gera-se, aqui, o pleito com França, que defendia a obra como sendo da autoria do conde de Guilleragues (secretário de Luis XIV e também escritor), tal como o provaria o privilégio real que lhe teria sido atribuído para publicação da obra. A contenda entre portugueses e franceses pela apropriação patrimonial da obra durará mais de dois séculos.

${ }^{2}$ Factor que talvez justifique a instabilidade dos títulos sob os quais apareceu a obra, desde a edição princeps en 1669: Lettres d'une religieuse portugaise traduites en français (edição de Pierre du
} 
em volta dela. O nosso interesse por esta obra vem do seu potencial heurístico e epistemológico, que gerou reflexões e discussões acerca do problema da autoria (portuguesa ou francesa, masculina ou feminina), pertença patrimonial, géneros literários ou da isotopia temática do amor. Mais do que tais pontos, interessa-nos neste artigo ${ }^{3}$ a relação dialética e a função da tradução com / na cultura portuguesa, de acordo com a teoria polissistémica. Assim, e de acordo com Hermans, tratar-se-á aqui de uma investigação que põe as literaturas e as culturas em contacto, entendidas numa relação de interdependência:

[...] a view of literature as a complex and dynamic system; a conviction that there should be a continual interplay between theoretical models and practical case studies; an approach to literary translation which is descriptive, target-oriented, functional and systemic; and the interest in the norms and constraints that govern the production and reception of translations, in the relation between translation and other types of text processing, and in the place and role of translations both within a given literature and in the interaction between literatures (Hermans, 1985: 10-11).

Com o que Bassnett y Lefevere designaram, em 1999, por "viragem cultural" nos estudos de tradução durante os anos 70, a teoria do polissistema de Even-Zohar apresenta-se como um conceito favorável ao alargamento da visão fossilizada da literatura traduzida, até então quase exclusivamente apoiada nos aspectos linguísticos e literários, a fim de ser entendida como um sistema de relações de interdependência com outros sistemas na cultura de recepção, como afirma Christine Zurbach: "Sans être toujours visible ou clairement énoncée comme telle, la traduction collabore activement dans les stratégies qui modèlent la communication entre les sociétés différentes, en mani-

Marteau, sans date); Lettres Portugaises: seconde partie (edição de Barbin, 1673); Lettres amoureuses d'une dame portugaise (Amsterdam, Isaac Van Dyck, 1677); Lettres d'une religieuse portugaise et du chevalier*** (Bruxelles, François Foppens, 1714); Lettres nouvelles d'une dame portugaise, avec ses réponses. Traduites en Français (Paris, Jean Ribou, 1722); ou Lettres d'une chanoinesse de Lisbonne à Melcour (la Haye, 1770). Em 1686, estas cartas são publicadas em Lyon, por François Roux e Claude Chize, e e apresentam três títulos diferentes : Lettres portugaises avec les responces; Lettres portugaises avec les responces, traduites en françois e Seconde partie des lettres portugaises traduites en françois. Em 1690, Corneille de Graef publica estas Cartas sob o mesmo título da segunda edição de Barbin e a primeira de Pierre du Marteau. Três décadas após a primeira edição de Barbin, as Cartas são publicadas por François Roger, em Amsterdam, num Recueil de Lettres Gallantes et Amoureuses d'Héloise à Abailard, d'une Religieuse Portugaise au Chevalier**. Avec celles de Cleante \& de Belife \& leur réponse [sic] (1699).

Isaac Van Dyck tinha-as publicado, em 1669, com um título mais simplificado, pelo qual as Cartas são comummente designadas: Lettres portugaises. Optaremos, portanto, por este título mais simplificado (ou, alternativamente, simplesmente por Cartas) para designar de ora em diante as cartas atribuídas à religiosa de Beja.

${ }^{3}$ Cujas reflexões foram mais aprofundadas na nossa tese de Mestrado, já defendida e publicada (Paradinha 2006). Este trabalho não pretende trazer novas luzes a esse assunto, serve, apenas, para divulgar aqui algumas das conclusões mais pertinentes desse estudo. 
festant une tendance pour influencer et intervenir dans la dynamique interne de l'univers de sa réception, dans les normes et les modèles qui définissent le comportement linguistique, textuel, culturel et idéologique de celui-ci” (2001: 245).

Entender que toda a tradução é, nas palavras de Theo Herman citado em epígrafe, "manipulação" permite-nos, assim, um entendimento mais alargado da tradução, que nos levou à análise dos discursos metatextuais dos tradutores e introduzindo, como linha de investigação no nosso estudo o carácter "ideológico" da tradução, de acordo com Lefevere (Bassnett, 2001: 295-299). Entendemos manipulação, ${ }^{5}$ no contexto da tradução literária, como uma intervenção manual que resulta de mecanismos intelectuais que conduzem às modificações de um texto de partida (hipotexto) tendo por finalidade a produção de um outro texto numa outra língua (hipertexto), ${ }^{6}$ quer se trate de modificações resultantes da transcodificação (Snell-Hornby) ou de manuseamento dos códigos linguísticos, quer o resultado de motivações ideológicas (individuais ou colectivas) do(s) tradutor(es), e que os levam, consciente ou inconscientemente, a fazer escolhas em relação ao que, no texto de partida, pretende $(\mathrm{m})$ guardar, transformar ou ignorar no texto de chegada. É neste sentido que empregamos, neste trabalho, o termo manipulação (Paradinha, 2006: 23-24).

\section{(In) visibilidade e ideologia do tradutor}

Com base no discurso e nas práticas dos tradutores para língua portuguesa das Cartas, pretendeu-se traçar o cruzamento dos planos político, ideológico e literário que nos parece visível nesta obra. Da mesma forma, o tratamento editorial e a canonização literária da obra permitiram-nos situar a tradução das Lettres portugaises no cruzamento dos planos social, ideológico e educativo. É preciso sublinhar que as traduções a que nos referimos abarcam um largo período de sensivelmente dois séculos (a primeira tradução da obra para português é do poeta Filinto Elísio e data de 1819, a última contemplada neste estudo é de Pedro Tamen e foi publicada em 2000), distribuídas por catorze tradutores que deram o seu nome à tradução e dez traduções anónimas. O número de traduções e de tradutores faz-nos reconhecer esta obra como uma fonte de contínua renovação estética e um estimulador de renovação linguística e literária. A mesma renovação constante mostra o potencial enunciativo da obra que origina reescritas, não só numerosas, mas também variadas a nível estilístico, o que dotaria a obra de um carácter místico que defendem Dilthey e Walter Benjamin ( $c f$. Steiner,

\footnotetext{
${ }^{4} \mathrm{O}$ termo manipulação, por nós traduzido directamente do inglês, não terá nada de negativo ou vicioso no âmbito dos Estudos de Tradução, já que, aplicado à "escola da manipulação" (tradução de João Ferreira Duarte in Bassnett 2001:298), reconfigura a abordagem, até então, estructuralista da tradução.

${ }^{5}$ Clarificamos aqui o emprego do termo, já que a sua polissemia levou, nos Estudos de Tradução, a aplicações um tanto ou quanto ambíguas e, por vezes, pouco transparentes.

${ }^{6}$ A propósito das noções de "hipotexto" e "hipertexto", veja-se Genette (1982).
} 
1998: 345), pois tais reescritas impedirão a obra de cair no esquecimento, tornando-a viva na memória dos homens.

Parece-nos importante destacar que, no que respeita aos tradutores, ressaltam dois aspectos: por um lado, as traduções são assinadas por figuras de renome e reconhecido valor no panorama literário português (poetas, historiadores, literatos e até mesmo políticos, ou literatos no desempenho de funções políticas). Por outro lado, nenhuma mulher figura entre os nomes dos tradutores, ${ }^{7}$ o que não corrobora a afirmação de Sherry Simon sobre a afinidade histórica entre a tradução e a mulher, análogas na sua condição de submissão: "[t]ranslators and women have historically been the weaker figures in their respective hierarchies: translators are handmaidens to authors, women inferior to men" (Simon, 1996: 1). Considerando uma certa imagética tradicional aplicada à tradução, na qual as relações hierárquicas entre o original e a tradução se baseiam em representações do homem e da mulher - "the original is considered the strong generative male; the translation the weaker and derivative female" (Simon, 1996: 1) ou ainda pelos tropos dominação / inferioridade, fidelidade / libertinagem—, seria perfeitamente aceitável que fossem as mulheres a ocupar este lugar de inferioridade histórica e discursiva, o que não se verifica no caso da tradução das Lettres portugaises. ${ }^{8}$ Por outro lado, a adulação abnegada de Mariana Alcoforado pelo oficial francês (na ténue fronteira entre a expressão máxima da entrega amorosa desinteressada e a vivência ingénua e patética de um amor que não só não é correspondido como ainda a despreza) assim como a carga nihilista que comporta este amor incondicional seriam razões defensáveis para que nenhuma mulher quisesse assinar a tradução (Paradinha, 2006: 35-36). O texto serviu, contudo, algumas manifestações literárias femininas, mormente próximas da Revolução dos Cravos, em 1974, em Portugal. A tardia (século XX) visibilidade da inspiração feminina num texto tão subversivo aos códigos morais talvez permita encontrar uma justificação defensável na problematização do sexo ("gender") do tradutor, no caso das Lettres portugaises. De outra forma, como entender que um homem traduza (aqui, na dupla acepção da palavra, inter e intra-linguística) melhor o sentimento da Mulher que uma delas, se, como defende Filinto Elísio, um bom tradutor sê-lo-á tanto mais quanto mais se identificar com o autor (s. d.: 13)? Posicionando-nos segundo o princípio de que "women's texts are translated only by women translators, men's by men" (Simon, 1996: 3), não seria mais legítimo encontrar a tradução das Cartas feita por uma mulher, para melhor expressar o sentimento feminino? (Paradinha, 2006: 36). Também tardio é o aparecimento das traduções anónimas (1902), o que nos pode levar a acreditar que fossem estas traduções de mulheres. Tenham elas sido traduções de autoria feminina ou masculina, esta tradução anónima privilegia a autoria da religiosa portuguesa, já que nenhum outro nome figura na capa do livro mais que o seu nome, Mariana Alcoforado.

\footnotetext{
${ }^{7}$ Apenas na terceira carta, na ordem de Barbin, recentemente traduzida por Diana Almeida, consta o nome de uma tradutora da obra.

${ }^{8}$ Estando as mulheres privadas durante muito tempo do direito à autoria, estas ter-se-ão, inicialmente, dedicado à tradução como forma camuflada de expressão, aceite publicamente, e prática de aprendizagem do trabalho de escritor (Simon, 1996: 2).
} 
No caso das Lettres portugaises, parece ter sido importante que a tradução fosse não só assegurada por homens, como ainda por homens de destacado relevo e reconhecido valor no panorama social e cultural português. Tal leva-nos a crer que a tradução masculina das Lettres portugaises serviu uma espécie de força, de virilidade, de que precisariam as Cartas para se impor nas culturas de partida e de recepção da obra.

As traduções portuguesas das Cartas gozam ainda de uma grande instabilidade de definições: ora se apresentam como "tradução" ou "nova tradução", ora como "versão", ora como "tentativa de texto português", ou até mesmo se assumem como "restituição" ou "nova restituição". Os primeiros termos ("tradução" e "versão") não causam grande perplexidade. Contudo, vejamos como a designação "tentativa de texto português" (e não "tentativa de texto em português") coloca o acento sobre "o texto" que, entendese pela adjectivação, é português —o que, nítidamente, não aconteceria no caso de se utilizar a preposição. O mesmo acontecerá com as traduções que se publicam como sendo uma "restituição" do texto. Este posicionamento dos tradutores (visível desde a tradução do Morgado de Mateus, em 1823) levou mais tarde à afirmação (e crença) de que, traduzindo a obra do francês letra a letra, se obteria, com toda a transparência, a sintaxe portuguesa e, portanto, o texto português original. Por entre os tradutores que publicaram a sua tradução designando-a como tal, encontram-se Filinto Elísio e Pedro Tamen, cujas motivações parecem ter sido linguístico-artísticas. A posição destes tradutores parece ter sido a mesma do também poeta e tradutor das Cartas, Eugénio de Andrade, que afirmava: "Foi nosso propósito, ao traduzirmos, há já um bom par de anos, as Cartas atribuídas ainda por alguns à freira de Beja, servi-las e não servirmo-nos delas" (Andrade, 1969: 11, ênfase nossa). A prática destes tradutores com motivações supranacionalistas assume-se, assim, como um exercício politicamente desprendido:

\begin{abstract}
Não nos propusemos qualquer restituição, no sentido de arriscada incursão no tempo, para a qual nos faltava saber e nos sobrava escrúpulo. [...] Que haveríamos de fazer? Procurar um apaixonado e lírico veio português que poderia correr entre tanta subtileza e galanteria, delícias de monsieur de Guilleragues? Impossível; a isso não nos atrevíamos. Cada leitor terá, assim, de o procurar sem a nossa ajuda, se nisso estiver empenhado. [...] Notar-se-á ao primeiro relance que, como tradutor, nenhum partido tomámos na querela da atribuição das Cartas. [...] Insistimos: nenhum partido tomámos, excepto o de servir a beleza das Cartas que, nalguns passos, é de tal modo excessiva que não há imprecisões ou incoerências que cheguem para a diminuir (ibidem: 11-13).
\end{abstract}

Esse desprendimento político ver-se-á também no tipo de edição da obra: contrariamente às traduções implicadas ideologicamente que aparecem editadas em colecções como "Novela Portuguesa", "Lusitânia", de pendor marcadamente nacionalista, as traduções dos poetas portugueses sem motivações ideológicas aparecem inseridas em colecções de carácter mais universal ou tendencialmente mais artísticas ("Arte de Amar" ou "Documenta Poética") e são frequentemente acompanhadas de tratamento artístico (edições especiais, edições de luxo, colaborações de artistas plásticos). 
O Morgado de Mateus e todos os restantes tradutores que o tomaram como modelo parecem, contudo, mais preocupados em servir-se da obra do que em servi-la e, portanto, mais empenhados na restituição patrimonial da obra, na procura do palimpsesto, produzindo obras menos próximas ou menos imitativas do texto francês, desafiando a sua originalidade e desautorizando, desta forma, a autoria francesa do texto. A maior parte das reescritas dos tradutores que se posicionam ideologicamente em relação às Lettres portugaises procuram uma fidelidade não ao texto francês mas ao orignal perdido. Estas posições dos tradutores parecem estabelecer as relações conflituosas de poder não só entre as traduções, mas ainda entre estas e o texto-fonte. As designações que os tradutores adoptam para as suas traduções parecem revelar, assim, o propósito de cada uma das traduções e a natureza de cada uma destas diferentes reescritas: uma tradução que se assuma como "tradução" reconhece o texto-fonte na língua francesa e parte deste para uma tradução mais "target-oriented" ou mais "source-oriented"; enquanto que um texto que se defina como "tentativa de texto português" ou "restituição" se auto-proclama, à partida, como um texto que se pretende visivelmente demarcar do texto francês. Em alguns dos casos, esse distanciamento é de tal maneira visível que a tradução (como é o caso da de Afonso Lopes Vieira) procura mesmo a criação de um novo texto, com características mais coloquiais e linguagem mais fluida. Acreditava o tradutor que a freira, tal como uma mulher apaixonada que escreve ao objecto do seu amor uma carta, teria de escrever, como é dito, aliás, numa das cartas, como quem fala. $\mathrm{O}$ texto francês, tendo características de texto literário, não seria, assim, o texto original, já que a premissa de escrever como quem fala não teria sido respeitada. $\mathrm{O}$ procedimento deste tradutor passa por, primeiro, traduzir o texto francês para um estilo mais coloquial (ainda em francês) e, depois, a partir deste, fazer a tradução para português. Estes últimos tradutores (Afonso Lopes Vieira entre outros) parecem ir ao encontro daquilo a que Lawrence Venuti designou por "translator's invisibility". O termo aplica-se, segundo Venuti, à situação e actividade dos tradutores contemporâneos da cultura anglo-americana, segundo as quais o papel do tradutor se limita a apagar ou diluir as particularidades linguístico-estilísticas de um texto, dando a "illusion of transparency" (Venuti, 1997: 1), de forma a que este seja mais fluente em cada uma das variantes linguísticas da cultura de chegada. Todavia, é certo que os tradutores portugueses que assumem uma posição favorável à origem portuguesa das Cartas também encontram essa transparência no texto francês, que, segundo estes, deixa ver os "portuguesismos de forma". Tais tradutores considerarão, tal como defende Venuti, "that translation is not in fact a translation, but the "original" " (ibidem) e esta convicção explicará igualmente a intenção dos tradutores, visto o discurso dos mesmos ser manifestamente mais reivindicativo da origem das Lettres portugaises do que reflexivo acerca dos problemas que coloca uma tradução.

As diferentes motivações dos tradutores deram, por conseguinte, lugar a um (vários) texto(s) marcado(s) por uma forte instabilidade estilística, como se patenteia no esquema abaixo: 
$282 \square$ MANIPULAÇÃO, TRADUÇ̃̃o LITERÁRIA E IDENTIDADE NACIONAL

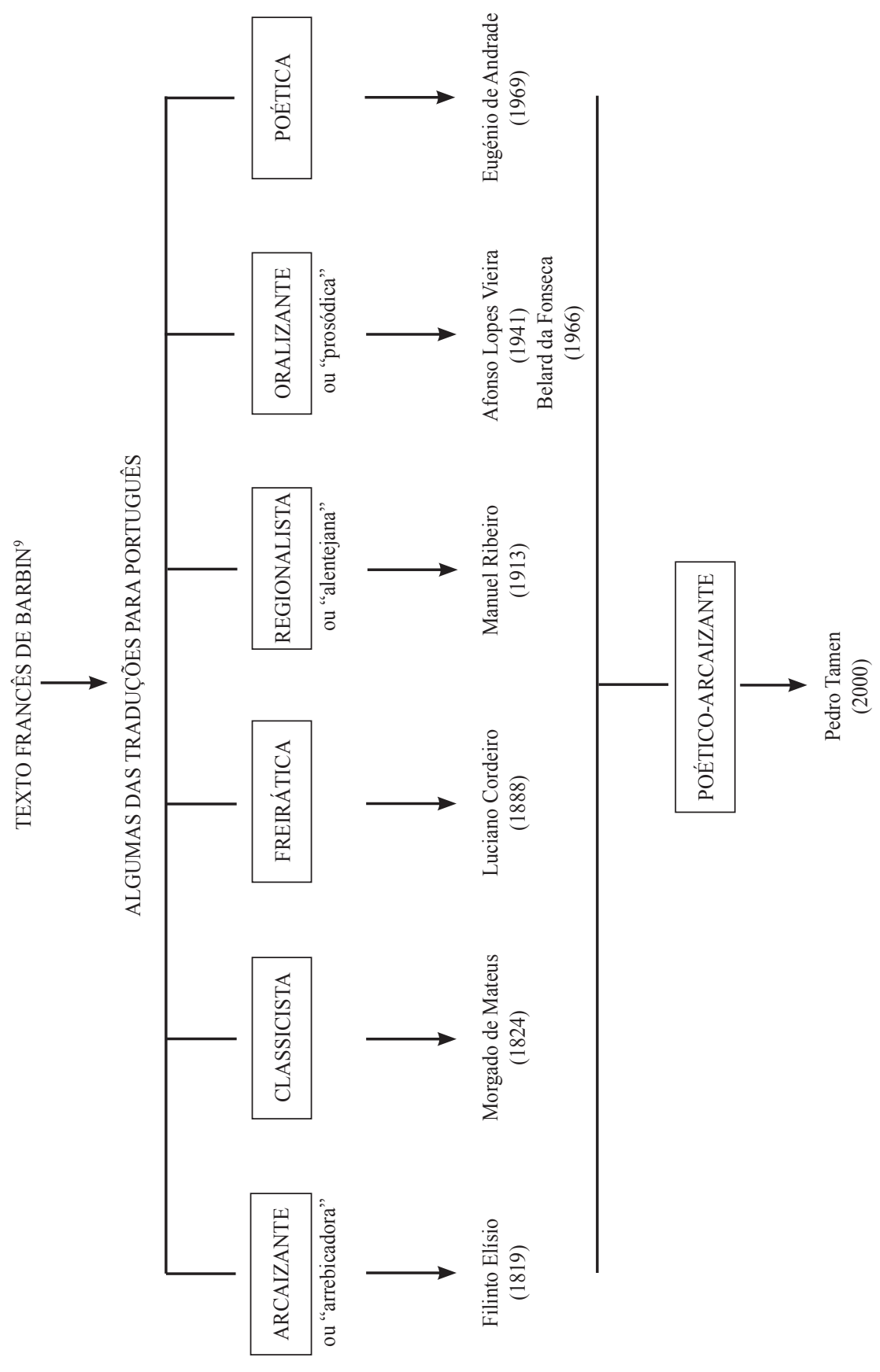

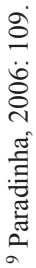


A questão que aqui nos preocupa é a de reflectir sobre a autoridade e o prestígio deste(s) texto(s) que pretendem, cada qual à sua maneira, ser o original português. Os desígnios patrimonialistas destes tradutores portugueses poderão ter imputado, do nosso ponto de vista, às traduções portuguesas um rótulo paradoxalmente mais desprestigiante e uma posição ainda mais subalterna em relação ao texto-fonte. Os esforços de despromoção do hipotexto (a partir do qual se originam as restantes reescritas) a hipertexto mais não fará que reduzir as traduções a hipertextos de um outro hipertexto (a hiper-hiper-textos?), que reduzem, por sua vez as próprias produções traductícias a literatura em terceira mão, imitativas da imitação, mais longínquas ainda do texto original perdido e mais dificultadoras da "restituição patrimonial" agenciada pelos tradutores com motivações nacionalistas.

A tarefa de encontrar o palimpsesto, ver-se-á, pois, comprometida, não só pela quantidade de tradutores e traduções da obra, como ainda pela variedade e instabilidade estilística por eles imprimida às mesmas.

\section{A saudade portuguesa e a especificidade do amor português}

A convicção destes tradutores posicionados ideologicamente em relação às Cartas levou ao levantamento da questão da especificidade da saudade portuguesa e do amor português, que seriam, como se defende, já tão conhecidas fora de fronteiras que se prestavam a explorações caricaturais na lírica e no teatro, antes mesmo das Lettres portugaises virem a público, como testemunha a oitava de Lope de Veja (1562-1635):

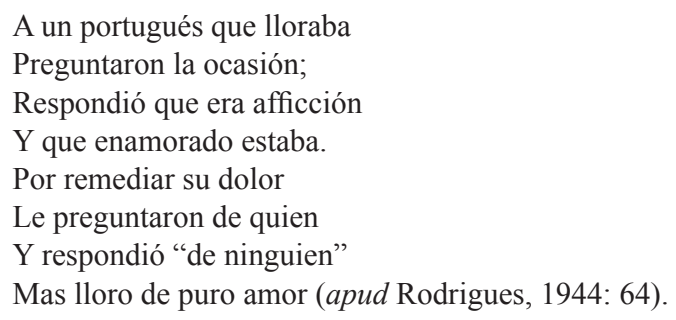

A crença no reconhecimento, não só nacional mas também universal, dessa especificidade levou Jaime Cortesão, a afirmar que a maior prova da paternidade desta obra estava no discurso amoroso, já que "pela boca de Soror Mariana falam todas as puras amantes de Portugal". Citado entre outros tradutores por Nuno Figueiredo, este acrescenta ainda, no seu prólogo à tradução: "Mas para quê acumular citações? Todas e cada uma das páginas das Cartas poderiam constituir uma única e longa citação onde se pode ler a maneira portuguesa de amar, um dos traços característicos da maneira portuguesa de estar no mundo e de encarar a vida" (1977: 22). Este empenho em considerar as Cartas como sendo, por si sós, representativas e testemunhais do "amor português" (e da saudade, que lhe está associada) sem aprofundar (ou sequer apontar) as caracte- 


\section{$284 \square$ MANIPULAÇÃO, TRADUÇÃO LITERÁRIA E IDENTIDADE NACIONAL}

rísticas dessa especificidade é também prática comum dos tradutores com pretenções restitutivas da obra. Esta defesa patrimonial parte e fundamenta-se no anonimato e no título da obra (Lettres portugaises, Lettres d'une religieuse portugaise, entre outros) - que funciona para estes tradutores como uma espécie de espelho identitário — mais do que naquilo que, no texto, nos poderia levar a defini-las como reveladoras da especificidade do amor português.

Dirá categoricamente Manuel Ribeiro que “[a]s 'Cartas' são pois intérpretes de qualquer sintoma do particularismo português. Espelham de certo modo qualidades nossas. Projectam-nos. [Elas são a] encarnação da paixão da Raça” (1940: VIII). Contudo, a fundamentação desta afirmação baseia-se mais na crítica aos anteriores tradutores com convicções patrióticas menos vigorosas (por exemplo, as escolhas lexicais de alguns dos tradutores deixariam ver uma preferência pelas palavras de origem francesa do que as de origem portuguesa, como era o caso do emprego do verbo "suportar" (do francês "supporter") em lugar de "aguentar" ou "aturar"). Parece-nos, porém, evidente que tal argumento não serve a prova de que o(s) tradutor(es) precisariam para considerar este texto como um documento genuinamente português. Constataremos, assim, tratar-se aqui de um silogismo encontrado na relação entre o amor português, a expressão lírica do mesmo e a autoria portuguesa das Cartas que é ininteligível para qualquer estrangeiro, porém perfeitamente perceptível para sensibilidade emocional portuguesa. E de tal maneira é perceptível que a sua evocação, embora redutora, basta, sem qualquer tipo de argumentos, para que um português imediatamente se identifique com ele. Este silogismo, do nosso ponto de vista, redunda, contudo, numa circularidade viciosa e impenetrável (Paradinha, 2006: 117). Este amor-saudade, confinado ao espaço geográfico sentimental português, seria inexplicável intelectual ou cientificamente e apenas experienciável por um ser luso. Tal revestirá o sentimento amoroso de uma natureza mítica, que reflectirá a estrutura de um comportamento nacional. Outra questão deixamos, então, em aberto: até que ponto a literatura de um país, dadas as relações dialógicas entre as literaturas e sendo todas elas simultaneamente parte e desdobramento de um arquétipo comum ( $a$ Literatura), poderá realmente espelhar uma cultura, um "génio nacional", mormente quando este encontra os seus fundamentos no sentimento amoroso, pretensamente universal?

\section{A tradução como ensimesmamento}

Como anteriormente constatámos e como veremos ainda na questão da identidade nacional, a tradução das Lettres portugaises não parece reconhecer a estranheza ao texto-fonte, nem o poeta se posiciona como um agente mediador entre duas línguas e duas culturas. A tradução não funcionará, neste caso, como uma doxa onde os leitores (portugueses) se reconhecerão na obra por uma questão de aproximação dado o carácter universal da obra ou por uma afinidade com o Outro, mas onde se entende que o Outro é o Mesmo, já que o Outro já não é o diferente, o externo, o estrangeiro: é o semelhante, 
o interno, o nacional (Paradinha, 2006: 165). A prática traductícia não corresponde, assim, a um esforço de aclimatibilidade já que a tradução não "corresponde a uma forma de negociação ou de aculturação" (Zurbach, 1996: 137), consciente das diferenças culturais, do Outro como diferente, mas onde essas diferenças não são consideradas nem sentidas e, portanto, essas diferenças são apagadas: ela é, assim, entendida, como um produto do nacionalismo e um processo de dever patriótico. A tradução das Lettres portugaises para língua lusa contraria, assim, a natureza da tradução, cuja natureza deveria ser marcadamente alocêntrica e "un des facteurs principaux de croissance de la communication interlittéraire, interculturelle et internationale", como lembra ainda Zurbach (2001: 245, ênfase nossa), e resulta numa declarada incomunicabilidade com o Outro, numa alienação que confere à tradução um carácter intraliterário, intracultural e nacional (ista). O papel da tradução altera-se, aqui, visivelmente: em lugar de difusora de uma outra cultura, a tradução passa a ser divulgadora interna da própria cultura nacional, isto é, o seu papel passa a ter um pendor essencialmente propagandista. A tradução para língua portuguesa das Lettres portugaises revela-se, pois, sensível à História nacional da sociedade de recepção, e mostra, sobretudo, permeabilidade à história mítico-patriota da mesma, não só porque nela se inscreve, como porque a reescreve ou a redesenha (Paradinha, 2006: 165-166).

\section{A questão da identidade nacional}

Podemos constatar que as traduções das Lettres portugaises se intensificam a partir de 1870, ano que marca o início daquilo a que Manuel Loff (2002: 26) chamou "o século do Nacionalismo português (1870's-1975)". Por essa altura, outras preocupações históricas, mais ou menos associadas ao campo literário, ocuparam também a classe política e intelectual romântica, exaurida numa exegese mítica nacional, fundada na procura quase obsessiva de atavismos da "índole nacional" ou conceitos equivalentes como "alma nacional", "génio do povo" e "espírito do povo" ("Volksgeist") (Catroga, 1996: 69). As recorrentes teses versavam temas como a formação de Portugal, a secularização das suas origens e a indagação sobre as características deste povo cuja ancestralidade de fronteiras geográficas teria marcado profundamente as propriedades endémicas ou endógenas (a raça e a língua, nomeadamente) daquilo que se quis, tão ao gosto romântico, designar por "identidade nacional", e nas quais tomam parte, entre outros historiadores, os tradutores das Lettres portugaises, quer o liberal Jaime Cortesão quer o conservador Manuel Pinheiro Chagas (Catroga, 1996: 71). Visivelmente, tratou-se de um projecto patriótico de definição de uma ideossincrasia nacional, con fins reactivos, combativos e reconstrutivos, reflectido no fluxo de produção historiográfica nacional. De acordo ainda com Catroga, "a definição da idiossincrasia da 'alma nacional' adequava-se optimamente à estratégia apostada em legitimar historicamente a refundição de uma nação que, estando decadente, necessitava de se regenerar" (ibidem: 70). Esta corrente romântica, "ideologicamente nacionalista" (Reis, 1999: 427) 
ou patriótica, ${ }^{10}$ exalta a especificidade da História da nação, sobretudo apoiada num passado imperial venturoso e outras figuras míticas da História medieval portuguesa, porém carentes de uma orientação objectivamente histórica, que "favorece[ram] uma nostalgia passadista, bem como uma certa idealização de figuras e costumes históricos, não raro restituídos de forma artificial e ideologicamente tendenciosa" (Reis, 1999: 428). A memória de figuras-ícones da cultura nacional foi profusamente eternizada pela arte monumental e pela estatuária, e amplamente divulgada pela diversa representação icónica, pela numismática, pela filatelia, pelo teatro e pelas aparatosas comemorações centenárias empreendidas pelo movimento nacional(ista), anterior à República, até ao Estado-Novo. ${ }^{11}$ Durante todo este período, parece, então, evidente a necessidade que a nação tem de se alimentar da cultura para sua sobrevivência, afirmação e/ou robustecimento. Dadas as datas em que tiveram lugar, os discursos metatextuais que as acompanharam e as práticas dos tradutores, as traduções portuguesas das Lettres portugaises não estiveram, manifestamente, alheadas desta sede patriótica do "nacionalismo português". Diríamos mesmo que elas se encontram um lugar central, juntamente com outros elementos passíveis de valorização patrimonial, no combate ao esquecimento e na renovação da força criativa e produtora de uma nação. Vejamos, a título de exemplo, o que é dito num dos prólogos da tradução das Cartas:

\footnotetext{
${ }^{10}$ Após a perda da independência em 1580 e a subordinação à dominação filipina, o povo português terá tomado consciência da sua identidade nacional (Mattoso 2003: 19), apesar da constatação irónica de que a publicação d' Os Lusíadas (1572) — texto apologético "que aparentemente sintetizou sob forma ideal a representação da própria identidade", como referiu Hélio Alves (2003: 1) — de Luís de Camões, se verifica pouco antes desse acontecimento traumático para Portugal. Contudo, será mais precisamente a partir do Ultimatum de 1890, com a Inglaterra, que a noção de identidade nacional ganhará uma dimensão mais alargada e popular (Mattoso, 2003: 38). É, aliás, neste mesmo ano que Alfredo Keil compõe o canto patriótico A Portuguesa, para o qual Henrique Lopes de Mendonça faz os versos, e que foi, em 1911, adoptado como o hino nacional potuguês.

${ }^{11}$ Num país de tradição dramática pobre, representam-se peças reveladoras da resistência das figuras histórico-míticas à passagem do tempo. Sem fazer uma lista exaustiva, os exemplos são numerosos: Aljubarrota (1912), de Rui Chianca; O Infante de Sagres (1916) e Egas Moniz (1918), de Jaime Cortesão; Vasco da Gama de Silva Tavares; Pedro, o Cru (1918) e Dinis e Isabel (1919), de António Patrício; o episódio sebastianista Cavalgada nas Nuvens (1922), de Carlos Selvagem, ou Viriato (1923), de Luna de Oliveira (Luiz Francisco Rebello, apud Torgal 1996:221).

As comemorações, mais frequentes nas últimas décadas do século XIX, amiúde acompanhadas de inaugurações de estátuas e representações iconográficas na numismática e na filatelia, compreendem o cortejo cívico em honra de Camões (1880), no âmbito das Comemorações do terceiro centenário da sua morte; o I Centenário do Marquês de Pombal (1882); o $7^{\circ}$ centenário da morte de D. Afonso Henriques (1885); o Centenário do Nascimento de D. Herique (1894); o centenário da viagem de Vasco da Gama à Índia (1897-1898); o Centenário da Guerra Peninsular (1909); os centenários de Ceuta e Albuquerque (1915); o centenário do nascimento de Vasco da Gama (1924); a Exposição do Mundo Português (1940) — comemorações do duplo centenário; ou as Festas do $8^{\circ}$ Centenário da Tomada de Lisboa aos Mouros (1947). Também na mesma linha, há a registar a consagração de Nuno Álvares Pereira como padroeiro da nação (1918).
} 
O livro que hoje damos à estampa traduz o propósito - melhor diríamos, o nosso dever patriótico - de acudir à boa tradição. Situa-se portanto no pólo oposto da tendência que porfia em arrancar ao espírito português o título desvanecedor de ter criado uma obra imortal, enternecidamente admirada por muitas gerações e que estimulou uma revolução de tal alcance na arte de exprimir a paixão de amor, que fez dizer o alemão Von Valdherg que a obra de Mariana Alcoforado é a chave da transformação do romance sentimental moderno (Ribeiro, 1940: VIII-IX, sublinhado nosso).

A canonização desta obra, incluída no ensino nos programas de Literatura Portuguesa, parece obedecer a critérios menos estéticos e mais propagandísticos, servindo, portanto, os interesses da nação. Mutatis mutandis, a centralidade canónica d' Os Lusíadas parece ter sido igualmente motivada por critérios exteriores aos da recepção estética, de acordo com Hélio Alves:

Quando a sobrevivência duma nação, ou seja dum poder ideologicamente homogéneo reflectido num Estado, se entrelaça com a centralidade canónica de um texto ou persona mais ou menos heróica, uma real fruição literária só se torna possível fora das fronteiras do imperium. O cânone nacional rejeita a valoração poética ou fá-la funcionar como mera pátina duma consistência canónica alheia da fruição estética. Por outro lado, a obra que, por algum conjunto de motivos históricos, se vai escoando até ser haurida esteticamente por uma recepção exterior à simbolização ideológica nacional, só poderá ver-se incluída no cânone imperial se não ameaçar seriamente os interesses que o agenciam desde início (2003: 2). ${ }^{12}$

À semelhança desta obra central do cânone literário nacional, a inclusão de uma obra de reconhecido valor estético a nível mundial, como são as Lettres portugaises, engrossa e enriquece o panorama literário português, servindo os interesses imperiais culturais de um país perseguido pelo lastro da periferia a que estava votado e que tentou sempre contrariar. Por outras palavras, a defesa da literatura canónica parece, no caso das Lettres portugaises, ser orientada política ou ideologicamente, pois a escolha do cânone literário revela ter sido accionada ou mesmo estimulada por critérios de aceitação e de rejeição menos artístico-literários e mais politizados, de acordo com a ideologia vigente no período Romântico e em perfeita harmonia com a ideologia estado-novista (Paradinha, 2006: 135). A não-aceitação da rendição de Portugal ao seu fado, ao lastro da periferia, a nação pugna por um excepcionalismo português, já que se

${ }^{12}$ A propósito da valoração estética d'OS Lusíadas, veja-se a opinião de Harold Bloom: “Os Lusíadas, do grande Luís Vaz de Camões, dir-se-ia também um texto épico-ideológico, mas tem uma imensa inventividade, exuberância, algo que se assemelha à mestria de Virgílio" (in Diário de Notícias, 23 de Maio de 2001). Também Hélio Alves reconhece o poder estético da obra, mas a sua posição a respeito da sua inclusão no cânone é mais céptica: "A epopeia de Camões continuará a providenciar leituras compensadoras a nível estético; pelo menos, creio que tal é possível e desejável. Porém, se assim for, há-de explicar-se às novas gerações em que é que a valia estética do poema continua a justificar a sua centralidade canónica" (Alves, 2003: 3-4). 


\section{$288 \square$ MANIPULAÇÃO, TRADUÇÃO LITERÁRIA E IDENTIDADE NACIONAL}

enfrenta, por alturas da Revolução dos Cravos, ao questionamento da grandeza do seu império, com a agudização do conflito colonial. Presa ainda à figura messiânica de D. Sebastião, imortalizada n' Os Lusíadas de Camões, a nação (e o império português) terá encontrado, no mito de Mariana Alcoforado, um novo valor literário de que precisava, canonizado na Exposição do Mundo Português de 1940, um Camões renovado.

\section{Obras citadas}

ALves, Hélio. 2003. ““As Memórias Gloriosas’ e o Inglório Esquecimento: Na(rra)ção e Canonização nos Lusíadas de Camões e no Sepúlveda de Corte-Real”. www.3dstudionet.com.br/e-book

ANDRADE, Eugénio de (trad.). 1969. Cartas Portuguesas atribuidas a Mariana Alcoforado. Porto: Inova.

BASSNETT, Susan. 2001. "Da Literatura Comparada aos Estudos de Tradução”. Helena Buescu, João Ferreira DuArte e Manuel Gusmão, org., Floresta Encantada. Novos Caminhos da Literatura Comparada. Lisboa: Publicações D. Quixote.

CATROGA, Fernando. 1996b. "Ritualizações da História". Luís REIS TORGAL et alii, dir. História da História em Portugal —séculos XIX e XX. [s. 1.]: Círculo de Leitores.

FigueIredo, Nuno de. 1977 [1974]. Cartas Portuguesas. Soror Mariana Alcoforado. Mem-Martins: Publicações Europa-América.

GeNeTTE, Gérard. 1982. Palimpsestes. La littérature au second degré. Paris: Éditions du Seuil.

HeRmans, Theo. 1985. The Manipulation of Literature: Studies in Literary Translation. London: Croom Helm.

LOFF, Manuel. 2002. "Um complexo nacionalista mal assumido". História, ano XXV (III série), Novembro de 2002.

Mattoso, José. 2003. A Identidade Nacional. 3a. ed. Lisboa: Gradiva. (Colecção Fundação Mário Soares)

PARADINHA, Maribel Malta. 2006. As Cartas de Soror Mariana Alcoforado. Manipulação e Identidade Nacional. Lisboa: Caleidoscópio.

REIS; Carlos. 1999. O Conhecimento da Literatura. 2a. ed. Coimbra: Almedina.

RIBEIRO, Manuel. 1940. Vida e Morte de Madre Mariana Alcoforado. Lisboa: Livraria Sá da Costa.

1923. Soror Mariana Alcoforado. Cartas de Amor. Lisboa: Livraria Editora Guimarães.

SimON, Sherry. 1996. Gender in translation. Cultural identity and the politics of transmission. London / New York: Routledge.

STEINER George. 1998. Après Babel. 3a. ed. Paris: Albin Michel.

VENUTI, Lawrence. 1997. The Translator's Invisibility: A History of Translation. New York: Routledge. 
ZURBACH, Christine. 2001. "La constitution d'un corpus d'étude en traduction. Le cas de la traduction théâtrale comme fait culturel". Deste Lado do Espelho. Estudos de Tradução em Portugal. Lisboa: Universidade Católica Editora.

. 1996. "Tradução e relações interculturais". Actas do II Encontro da Associação de línguas do Ensino Superior (APOCLES). Évora: Serviços de Reprografia e Publicações da Unoversidade de Évora. 